\title{
JAVA IN THE 14TH CENTURY $N \bar{A} G A R A-K \breve{E} R T \bar{A} G A M A$
}

\author{
VOLUME III
}




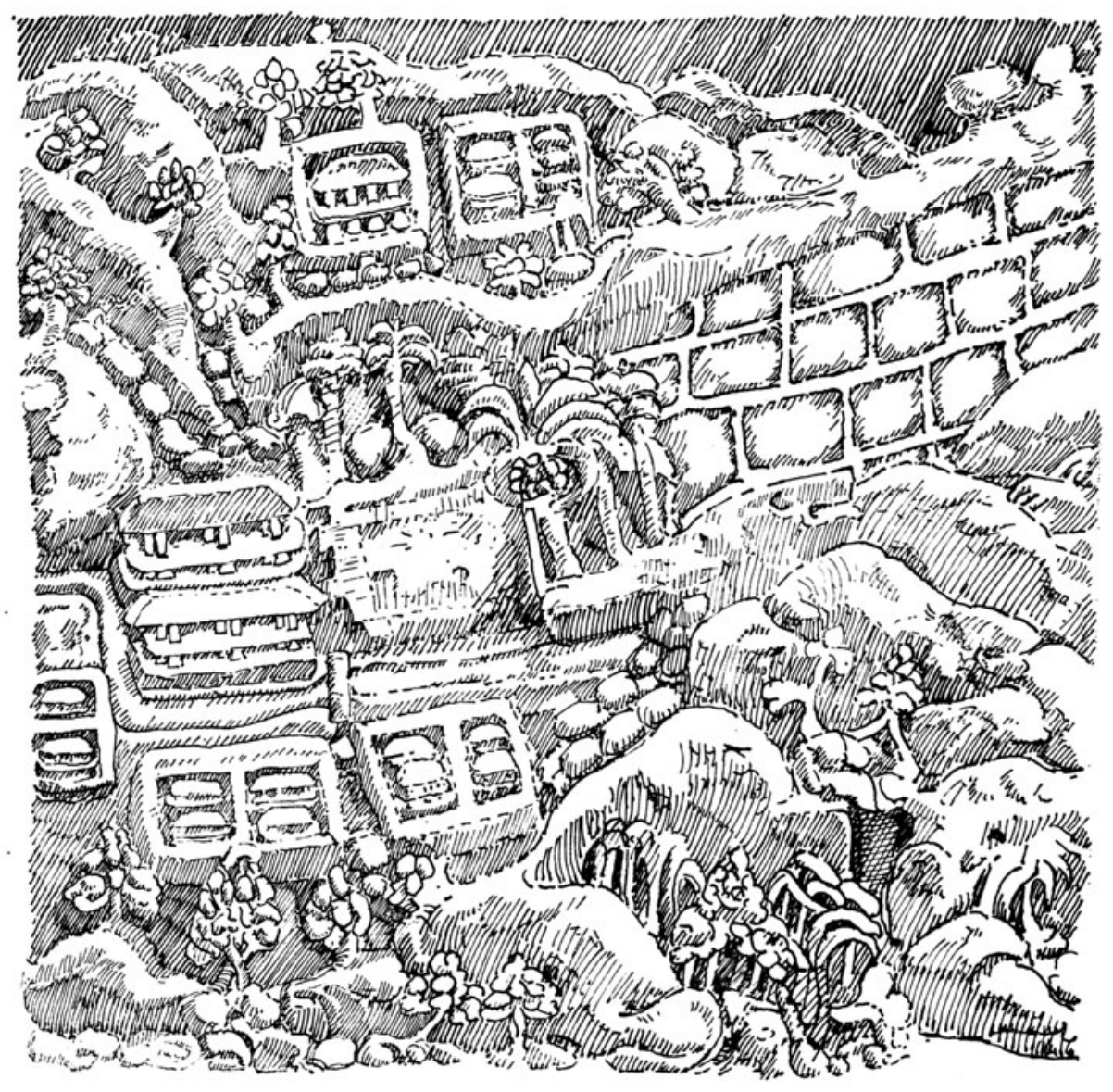

I. A BIRD'S EYE VIEW OF A MOUNTAIN VALE WITH A RURAL COMMUNITY. SEE P. VIII. 


KONINKLIJK INSTITUUT
VOOR TAAL-, LAND- EN VOLKENKUNDE
TRANSLATION SERIES 4,3
\&

\section{JAVA IN THE 14TH CENTURY}

A STUDY IN CULTURAL HISTORY

THE NĀGARA-K ĔRT ĀGAMA BY $R A K A W I$ PRAPA ÑCA OF MA J A PAHIT, 1365 A.D.

Third edition, revised and enlarged by some contemporaneous texts with notes, translations, commentaries and a glossary

by

THEOdORE G. Th. PIGEAUd, Рн. D. Leyden

Illustrated with drawings by Professor Th. P. GALESTIN

PUBLICATION COMMISSIONED AND FINANCED BY

THE NETHERLANDS INSTITUTE FOR INTERNATIONAL CULTURAL RF.LATIONS

\section{III}

TR A N SLAT I O N S

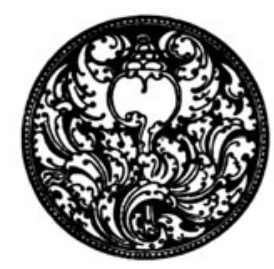

THE HAGUE - MARTINUS NIJHOFF - 1960 
ISBN 978-94-011-8149-5

ISBN 978-94-011-8772-5 (eBook)

DOI 10.1007/978-94-011-8772-5

Softcover reprint of the hardcover 1st edition 1960 
The complete work is in five volumes:

VOLUME I

JAVANESE TEXTS IN TRANSCRIPTION

VOLUME II

NOTES ON THE TEXTS AND THE TRANSLATIONS

VOLUME III

TRANSLATIONS

VOLUME IV

COMMENTARIES AND RECAPITULATION

VOLUME $\mathrm{V}$

GLOSSARY, GENERAL INDEX 
Translation of the Nāgara-Kĕrtāgama:

Chapter 1 - Introduction, the Royal Family of Majapahit about 1350 A.D. . . . . . . . . . . 3

Chapter 2 - Majapahit, the Capital, about 1350 A.D. . . 9

Chapter 3 - Tributaries and neighbours of Majapahit. establishment of the Royal authority by emissaries taken from the ecclesiastical officers

Chapter 4 - The Royal Progress of 1359 from Majapahit through the eastern districts of Java, and back to Singasari . . . . . . . . .

Chapter 5 - Notes on the Kings of the House of Rājasa, from 1182 till 1343 , and on their religious domains .

Chapter 6 - The Royal Chase in the neighbourhood of Singasari . . . . . . . . . . . . 56

Chapter 7 - The return from the Royal Progress of 1359, from Singasari to Majapahit . . . . . . 63

Chapter 8 - The Royal Progresses of 1360 and 1361 to Tirib, Sömpur and Blitar . . . . . . . 70

Chapter 9 - The posthumous ceremony in honour of the Rājapatnī, in 1362, her shrines and her cult

Chapter 10 - The Royal Progress of 1363 from Majapahit to Simping and back . . . . . . . . 82

Chapter 11 - Gajah Mada's death in 1364, the new officials . . . . . . . . . . . . . 83

Chapter 12 - List of domains belonging to the Royal Family and to religious communities . . . 86

Chapter 13 - Organization of the clergy and Royal authority . . . . . . . . . . . . . . 92

Chapter 14 - The annual Court festival in Majapahit . . 97

Chapter 15 - Conclusion . . . . . . . . . . . . 110

Translation of the Nāgara-Kĕrtāgama colophons . . . . . . 115 
Translation of the Minor Writings:

Nawanatya . . . . . . . . . . . . . . . . . 119

Rājapatiguṇạala . . . . . . . . . . . . . . . 129

Purwādigama preamble . . . . . . . . . . . . . 138

Praniti Raja Kapa-kapa . . . . . . . . . . . . . 139

Translation of the Charters:

Sarwadharma charter of 1269 , found in Pernampihan . . . 143

Decree Jaya Song, 1350, found in Bendosari . . . . . . 151

Ferry charter of 1358 , found in Trawulan and Pĕlèm . . . 156

Batur charter, found in Batur . . . . . . . . . . . 163

Biluluk charters of $1366-1395$, found in Bluluk . . . . 166

Rěnĕk charters of 1379 , found near Majapahit . . . . . 169

Walandit charter of 1381-1405, found in Pěnañjangan . . 171

Patapan charter of 1385 , found in Trawulan . . . . . . 172

Karang Bogěm charter of 1387, found in Trawulan . . . . 173

Katiden charter of 1392, found in Trawulan . . . . . . 174

Shela Mandi charters of $1394-1396$. . . . . . . . 175

Illustrations: drawings by Professor Galestin after stone reliefs of 14th century East-Javanese temples:

I. Frontispiece: A bird's eye view of a mountain vale with some square terraced rice-fields (sawah) to the right and compounds with dwellings in the centre and to the left. From the near side, at the foot of the drawing, a path is seen leading to a bridge over the rivulet at the bottom of the vale and past two six-pillared open halls, probably marking the centre of a religious rural community, perhaps a mandala, a sacred-centre community. The path goes further on into the hills at the opposite side of the vale where big stones supposedly must make the climbing easier. The trees that are planted everywhere are characteristic features of the Javanese countryside. Drawn after two separate relief-stones of Trawulan, most probably belonging together . . . . . . .

II. A battle: the party of five men (one lies on the ground, wounded) at the right apparently is trying to recover a Princess who is carried off by a Prince riding on the car drawn by four horses at the left. The attire and the weapons of the fighting men are peculiar. Several pursuers wear a headdress resembling the diadems (jamang) of modern Javanese wayang puppets and a kind of coats of mail as protection of the breast. They are armed with short pikes and round bucklers or with a kind of curved stabbing knives, daggers or small swords with tassels on the hilt, showing not much resemblance to modern Javanese crisses. Most men of the pursued 
party at the left (probably being of higher standing than the others) have their hair made up in a chignon at the back of their heads. Their weapons are the same as those used by the other party except for the bow of the Prince on the car. The decorated triangle is the car's wooden back-screen and the standing poles are the supports of the roof of plaited bamboo that has been removed for the occasion of the flight. Behind the wounded man's buckler the head and hand of a clownish servant (pandakawan) appear. Apparently he is trying to crawl away from danger. Drawn after a stone relief of Candi Panataran, central temple $( \pm 1347$ A.D.). Represented are scenes from the Old Javanese romantic poem Kĕrṣnāyana. The Prince's crown has been left out as belonging more to mythology than to real life. . . . . . . . . . . . . .

III. A bearded priest or hermit in sacerdotal attire: hair in a knot, earrings, band over the right shoulder, making the añjali gesture sitting cross-legged on a stone or brick dais. Apparently he is officiating in an offering ceremony: two similar sets of offerings (cones of cooked rice and various eatables on plates) are in evidence, one a little more elaborate than the other. They are placed on two decorated tables standing on separate daises accessible by means of some stone steps. At the side of the larger offering table a rather small stone structure of the shape of a small candi, a religious monument with a steeple roof, is shown. Probably it was an abode destined for a deity or deities of inferior rank, chthonic powers. In one corner of the drawing a low ivory-coconut palm, one of the priestly prerogatives, is visible, and in the other corner a closed house with a roof of shingles, standing on short supports on top of an elevated base of stone and brick. Probably it is the priest's sleeping place and storeroom for the utensils belonging to his office. Drawing (with some small changes in the figure of the priest) after a stone relief of the pẹndåpa-terrace of Candi Panataran (1375 A.D.) . .

IV. An empty hermitage or priest's compound showing in the background an undecorated table for offerings on a dais flanked on one side by a big waterjar and on the other by a small stone candi-like monument. The foreground is occupied by a small four-pillared open hall and a closed house, both on stone bases. The yard is planted with low shrubs. Another big water-jar is in evidence. Comparing the drawings III and IV it becomes clear that several features shown therein are characteristic of priestly surroundings in XIVth century East Java. Drawing after a stone relief of Candi Jawi, the foundation of King Kĕrtanagara of Singasari 
V. A Princess wearing earrings, a necklace and bracelets, having drawn her kain over her breasts as a token of religious reverence, is seen sitting on a rather high stone dais receiving food and drink that are offered her by a bearded ecclesiastical gentleman (accompanied by two male servants who carry things), standing, and his wife, sitting on the dais. The four clerical persons' headdress and apparel are characteristic of their state. The reverend gentleman and his wife wear the elaborate headdress belonging to male and female ecclesiastics shown also on drawing IV in the first volume and on drawing III in the second volume of the present book. Both wear bands over their left shoulders. The gentleman wears a long jacket with sleeves as token of his dignity. The first servant or disciple, who is carrying a plate laden with food, wears a kind of cap with a flap at the back. The second one, of lower rank, is carrying two bamboo containers with liquor suspended from a carrying-pole. His headdress is a kind of turban and, having to carry a rather heavy load. he has tucked up his kain above his knees. The Princess has before her a cup made of a bamboo section, for a refreshing drink after the journey. At the base of the dais are shown (probably): three stalks of sugarcane in a bundle (to be chewed for the sweet sap), two big fruits, perhaps Jack-tree fruits (Artocarpus integra, Javanese: nangka) and a jar with water. Probably the scene depicted on the relief is the ceremonial reception of a Princess in a hermitage where she is offered the regalement (sĕǧ̆h) prescribed by custom and due to her rank. The Princess's headdress has been left out. It has been replaced by the normal hairdress of a lady of rank. Drawing from a stone relief of the péndåpă-terrace of Candi Panataran . . . . 
The Dutch Nāgara-Kĕrtāgama translation on which Professor Kern worked, at intervals, during eleven years, deserves our utmost admiration and respect. It is the last important piece of work he finished before his death. It has enriched in an extraordinarily high degree our knowledge of the history and antiquities of the Majapahit period. Moreover, its dignified and courtly style established the reputation of Old Javanese letters as a literature of considerable interest. The contents of the Nāgara-Kĕrtāgama, as interpreted by Professor Kern, gave 14th century Majapahit a nimbus, making it appear to the uncritical public as a most powerful and highly cultured Empire, organized on 18th or 19th century West-European lines.

The notes of Krom, Poerbatjaraka and others do not contain complete translations of the texts. These scholars made valuable contributions to a better understanding of several passages. They did not make it easy for the general reader to consult their notes, though. Professor Kern's appreciation of the contents of the Nāgara-Kĕrtāgama remained fundamentally unshaken.

Up to the present time Professor Kern's Nāgara-Kĕrtāgama translation has been generally used and highly appreciated by students of Indonesian cultures and by the public interested in Old Javanese history, both in Indonesia and elsewhere. In 1953 a modern Malay translation by Slametmuljana was published in Djakarta (Negarakretagama, diperbaharui kedalam bahasa Indonesia). But then, since Professor Kern's days research has made progress. It is clear, nowadays, that his translation has the defects of its good qualities.

Surely no new translation can be expected to evoke the admiration and to arouse the affection of the public interested in Javanese antiquity in nearly the same degree as Professor Kern's did in his time. The present translator does not aspire to emulate Professor Kern. Perhaps students of Indonesian sociology and cultural history wil appreciate, though, a new edition with notes and commentary founded on the results of modern research, however prosy it may be.

Professor Kern's Dutch Nāgara-Kĕrtāgama translation makes pleas- 
ant reading because it is partly more of a paraphrase than of a literal rendering of the text. The present English translation, on the other hand, keeps as close as possible to the original. No doubt the arrangement of the sentences in the poem often was unusual even for 14th century Javanese readers. But then the Nāgara-Kĕrtāgama is a product of high poetical schooling conforming as far as possible to Sanskrit prosody and käwya rules. Considering this fact the present translator has felt justified to make free with English syntax. Only in this manner it proved possible to follow the Old Javanese text word for word, giving an English equivalent to all Javanese words of the original.

Another departure from the rule followed by Professor Kern in his translation is the following. Many Javanese words are left untranslated because they are to be considered as technical terms belonging to the idiom of the Royal Court, the chancery and the priesthood of 14th century Majapahit. As far as possible explanations of the meanings of the technical terms are given in parentheses in the translation, and further in the commentary and the recapitulation in vol. IV. They can easily be found by means of the glossary (vol. V), which serves as a general index to all Javanese words in the preceding four volumes. In the present translator's opinion, rendering foreign technical terms by English words which belong to a different sphere of thought, without mentioning the original word in the foreign language, inevitably causes the text to be misunderstood.

More or less in imitation of Dr G. P. Rouffaer, whose Inhoud van de zangen van de Nāgarakrtāgama (Contents of the Năg.'s cantos) has been appended to Professor Krom's edition of 1919, the present English translation is divided into fifteen chapters. In the Notes (vol. II) and the Commentary (vol. IV) each chapter is treated separately.

Except in the transcription of the texts in vol. I and the glossary in vol. V, Javanese words and names are spelled in accordance with modern custom. This makes it easier to recognize Old Javanese words that are still in use at the present time. As to Sanskrit words, in the translation and the glossary the regular Sanskrit spelling has been indicated if necessary.

The present, third edition of the Nāgara-Kĕrtāgama is the first one to be published in English. This will enable scholars who are not conversant with the Dutch language to take note of one of the most remarkable products of Old Javanese literary activity. Connoisseurs of Indian letters may possibly find something in it that reminds them of the best of Sanskrit literature. Nevertheless the spirit 
that pervades the text is peculiarly Javanese, as will be demonstrated in the commentary in vol. IV. The translations of the contemporaneous Minor Writings and Charters, mostly made expressly for the present book, may be found useful in providing informations on fourteenth century East-Javanese society. The study of that period is necessary both for the appreciation of Javanese books such as the Nāgara-Kĕrtāgama and for the understanding of the continuity in Javanese culture manifest up to modern times. 


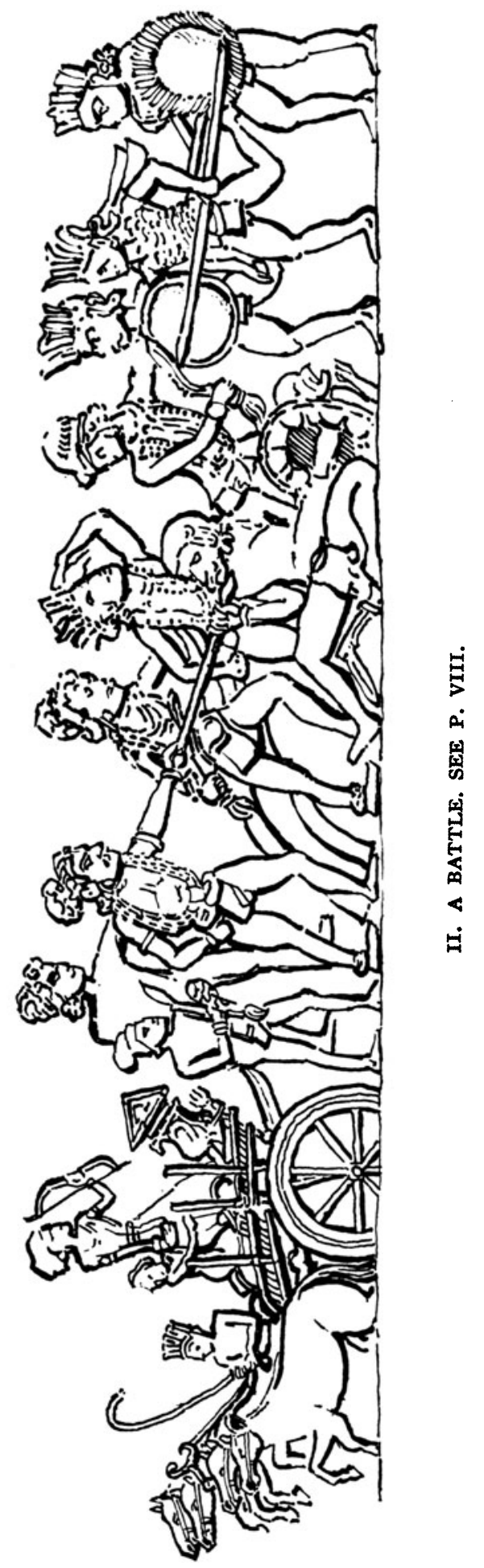

